\title{
AN X-RAY DIFFRACTION METHOD FOR DETERMINING THE AMOUNT OF XENOTIME IN A ZIRCON SAMPLE
}

\author{
RAGNAR TÖRNROOS
}

\begin{abstract}
TÖRNROOS, RAGNAR, 1984: An X-ray diffraction method for determining the amount of xenotime in a zircon sample. Bull. Geol. Soc. Finland 56, Part 1-2, 203-206.

An X-ray method was developed for determining the amount of xenotime or zircon in a zircon - xenotime sample. Such analyses are useful in establishing whether a solid solution exists between xenotime and zircon or whether there is a separate xenotime crystal phase. The method is applicable to compositions between 2 and 98 wt $\%$ of either xenotime or zircon.
\end{abstract}

Key words: Zircon, xenotime, X-ray method.

Ragnar Törnroos: Geological Survey of Finiand SF-02150 Espoo 15, Finland

\section{Introduction}

A vast amount has been written on the chemistry of zircon, and more than 50 elements have been reported in zircon analyses. Although some authors disagree (e.g. Görz 1974), most consider that of these elements yttrium, rare earths, uranium, thorium and phosphorus, substitute for $\mathrm{Zr}$ and $\mathrm{Si}$ in the lattice representing a solid solution of zircon with the isostructural xenotime (see Speer 1981, p. 74).

Coexisting xenotime and zircon are often reported as epitaxial intergrowths, overgrowths and inclusions (see Speer 1981, p. 75). Xenotime has been indentified by X-ray diffraction as intimate intergrowths in zircon from the Pyörönmaa pegmatite in Finland (Vorma et al. 1966) and as minute epitaxial intergrowths in metamict zircon samples from Zambézia, Mozambique (Törnroos 1982). Robinson (1978) showed by single crystal X-ray work that some varieties of zircon earlier reported as very rich in REE were zircon-xenotime intergrowths.
To my knowledge, however, no X-ray studies have been conducted to establish the amount of xenotime-phase present in zircon. My work on zircon material from Zambézia, Mozambique was neverthless severely hampered by the coexistence of xenotime and zircon. The xenotime (200)-line was always visible in the X-ray diffraction patterns, even after careful selection of the zircon grains. Figure 1 gives an example of xenotime epitaxially intergrown with zircon.

The yttrium, REEs, uranium, thorium and phosphorus found in the metamict zircon material from Zambézia build up their own phases, at least partly, within or together with the zircon (Törnroos 1982, Törnroos in preparation). The zircon and xenotime are very difficult to separate from each other and hence it was necessary to find a method to estimate their ratio or amounts.

Having received several enquiries about the method used to determine the amount of xenotime i zircon (Törnroos 1982), I shall describe the method in the present article. 


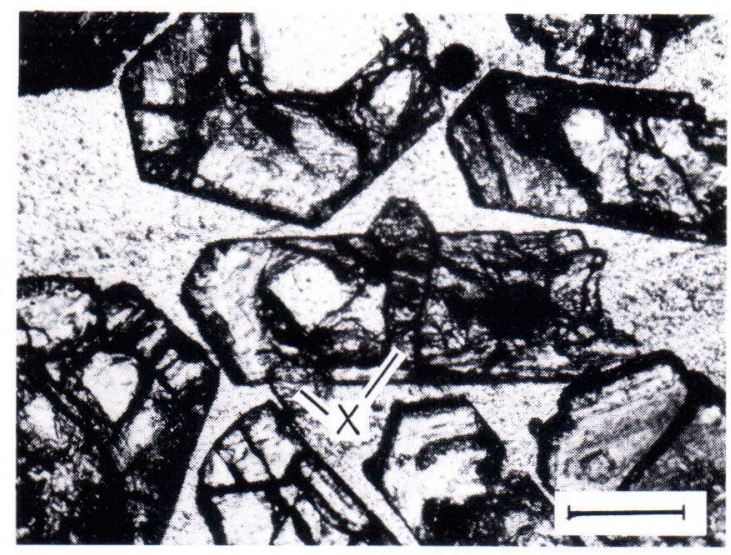

Fig. 1. Zircon with epitaxially intergrown xenotime (X). Specimen L.M. 4627, a zircon concentrate with euhedral prismatic crystals. Photomicrograph of polished thin section, plane polarised light. Length of bar $=0.15 \mathrm{~mm}$.

X-ray diffraction permits rapid approximate determinations of the amount of xenotime in zircon samples. The method is similar to that proposed by Tennant \& Berger (1957) for determining dolomite/calcite ratio in a carbonate specimen.

\section{Experimental}

The material used for this study was first crushed down to $100-400$ mesh, washed and then separated from the light material in Clerici solution. Pure grains were then selected, picked up under a stereomicroscope and ground in acetone in an agate mortar to obtain a sufficiently fine grain size $(3 \mu \mathrm{m})$.

\section{Standards and the method}

A series of standard preparations in which the amount of xenotime ranged from 1.0 to 98.2 wt \% (Table 1) was made using pure nonmetamict zircon from the Urals ( $D=4.57$ $\mathrm{g} / \mathrm{cm}^{3}$ ) and pure xenotime from Mozambique. The intensity ratios for the X-ray diffraction
Table 1. Composition of standard preparations and corresponding $\mathrm{X}$-ray intensity ratios.

\begin{tabular}{rcccc}
\hline No. & $\begin{array}{c}\text { Zircon } \\
(\mathrm{mg})\end{array}$ & $\begin{array}{c}\text { Xenotime } \\
(\mathrm{mg})\end{array}$ & $\begin{array}{c}\text { weight } \% \\
\text { xenotime }\end{array}$ & $\frac{\mathrm{I}_{\text {zir }}}{\mathrm{I}_{\text {xen }}}$ \\
\hline 1 & 19.8 & 0.2 & 1.0 & - \\
2 & 21.9 & 0.8 & 3.5 & 22.0 \\
3 & 29.0 & 2.1 & 6.8 & 14.1 \\
4 & 17.2 & 3.3 & 16.1 & 6.89 \\
5 & 15.2 & 5.8 & 27.6 & 3.44 \\
6 & 22.1 & 15.0 & 40.4 & 1.73 \\
7 & 12.5 & 15.1 & 54.7 & 1.05 \\
8 & 7.3 & 16.3 & 69.1 & 0.655 \\
9 & 5.3 & 20.6 & 79.5 & 0.350 \\
10 & 2.2 & 18.5 & 89.4 & 0.233 \\
11 & 1.4 & 19.3 & 93.2 & 0.103 \\
12 & 1.4 & 35.0 & 96.2 & 0.066 \\
13 & 0.5 & 26.7 & 98.2 & 0.026 \\
\hline
\end{tabular}

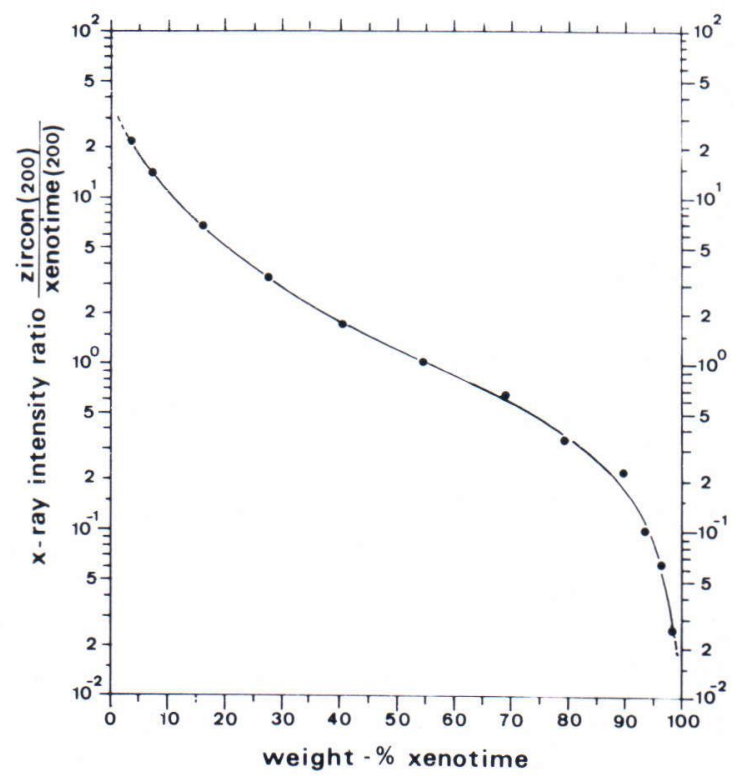

Fig. 2. Lin-log diagram for determining abundance of xenotime or zircon by means of X-ray diffraction in a zircon-xenotime sample.

lines (200) of zircon and xenotime were calculated. These ratios were plotted as a function of the abundance of xenotime in a lin-log diagram (Fig. 2). The X-ray diffraction lines were recorded with a Philips wide-angle goniometer and a Wallac single-channel analyser using Ni- 
filtered $\mathrm{Cu}$ radiation. The range for the measurements was $2 \theta=25^{\circ}-28^{\circ}$. The intensities for the $3.31 \AA$ zircon line and the $3.44 \AA$ xenotime line were obtained by planimetering the area under the peak.

\section{Results}

The method was tested with a series of preparations (Table 2) made using a slightly heated metamict zircon from Capunda, Angola and a non-metamict zircon from Muvumbi, Tanzania. The xenotime was the same as that mentioned above from Mozambique.

Table 2 gives the results of the intensity measurements and the corresponding abundance of xenotime graphically determined from Figure 2. The method is considered accurate to $\pm 5 \%$. For normal purposes this accuracy is satisfactory, and it is valid for both slightly heated metamict and non-metamict zircon specimens. Reservations are, however, made for completely metamict specimens, which give weak and diffuse diffraction lines, even after

Table 2. Mixed test preparations $(1-5)$ and analysed natural zircon - xenotime specimens $(6-11)$.

\begin{tabular}{|c|c|c|c|c|c|}
\hline \multirow[t]{2}{*}{ No. } & \multirow{2}{*}{$\begin{array}{c}\text { Zircon } \\
\text { (mg) }\end{array}$} & \multirow{2}{*}{$\begin{array}{l}\text { Xenotime } \\
\text { (mg) }\end{array}$} & \multicolumn{2}{|c|}{$\begin{array}{c}\text { weight percentage } \\
\text { xenotime }\end{array}$} & \multirow{2}{*}{$\frac{I_{\text {zir }}}{I_{\text {xen }}}$} \\
\hline & & & calcul. & graphic. & \\
\hline 1 & 20.9 & 1.1 & 5.0 & 5 & 18.0 \\
\hline 2 & 20.2 & 10.7 & 34.6 & 34 & 2.43 \\
\hline 3 & 17.3 & 19.0 & 52.3 & 55 & 1.04 \\
\hline 4 & 3.5 & 20.1 & 85.2 & 90 & 0.184 \\
\hline 5 & 1.5 & 20.7 & 93.2 & 94 & 0.109 \\
\hline 6 & & & $1.5^{*}$ & $<2$ & 100 \\
\hline 7 & & & 1.3 & $<2$ & 45 \\
\hline 8 & & & 2.6 & 3.2 & 23.1 \\
\hline 9 & & & 6.2 & 6.0 & 16.2 \\
\hline 10 & & & 10.0 & 8.3 & 12.8 \\
\hline 11 & & & 4.2 & $<2$ & 34 \\
\hline
\end{tabular}

Preparations 1 and 5, zircons from Muvumbi, Tanzania. Nos. $2-4$. heated $\left(1000^{\circ} \mathrm{C}\right.$ ca 3 hours $)$ metamict zircon from Capunda, Angola. Nos. $6-10$. heated $\left(1000^{\circ} \mathrm{C}\right.$ ca 4 hours) and analyzed metamict zircon from Mozambique. No. 11. non-metamict zircon from Mozambique. * 6-11 wt $\%$ based on analysed $\mathrm{P}_{2} \mathrm{O}_{5}$. prolonged heating. Table 2 (Nos 6-11) gives the results obtained from the analysed samples of Zambézia zircon - xenotime. They show that the method works satisfactorily on unknown specimens.

\section{Discussion}

The method is applicable to minerals isostructural with zircon and xenotime and which have about the same unit cell dimensions, in particular hafnon and REE-phosphates. The phosphates of the heavier lanthanoids from Dy to $\mathrm{Lu}$ are isostructural with xenotime but those of $\mathrm{La}-\mathrm{Tb}, \mathrm{Ca}, \mathrm{Th}$, and $\mathrm{U}$ are not. The $\mathrm{d}_{200}$ of the heavier lanthanoids range from $3.40 \AA$ to $3.46 \AA$ and is for hafnon $3.29 \AA$ (extrapolated value from Correia Neves et al. 1974).

In the samples of zircon from Zambézia the proportion of $\mathrm{Y}+\mathrm{REE}$ to $\mathrm{P}$ equals 1 (see Törnroos 1982, Fig. 2) and Y and the heavier lanthanoides predominate over the light ones. It is therefore suggested that the lanthanoides substitute for yttrium in the xenotime lattice, perhaps causing a broadening of the (200) X-ray line but no changes in the intensity ratios.

In their studies on zircons, Romans et al. (1975) and Medenbach et al. (1976) found that the atomic ratios of silicon to zirconium + hafnium were below 1.0 in regions with a high xenotime solid solution component, whereas ratios of yttrium + rare earths to phosphorus exceeded 1.0, thus requiring another charge balance mechanism. This implies that some phosphorus has substituted for silicon. However, the yttrium content tends to increase linearily towards lower $\mathrm{Si}(\mathrm{Zr}+\mathrm{Hf})$ ratios. Together with a xenotime phase xenotime may also exist in solid solution with zircon, as may be concluded from Table 2, where specimen No. 11 shows an excess of calculated xenotime over the X-ray data.

In conclusion, when studying "foreign» elements, particularly yttrium, rare earths and 
phosphorus, in zircon one must remember to check whether the xenotime occurs in solid solution with zircon or as a free xenotime-phase.

$\mathrm{X}$-ray diffraction gives us a handy tool for achieving satisfactory results. Because the Xray line of the minor component disappears at low concentrations, the method is restricted to the region between 2 and $98 \mathrm{wt} \%$ of either the xenotime or the zircon in the sample.

It must be emphasised that the method is ap-

\section{References}

Correia Neves, J. M.; Lopes Nunes, J. E. \& Sahama, Th. $G ., 1974$. High hafnium members of the zircon-hafnon series from the granite pegmatites of Zambézia, Mozambique. Contr. Mineral. Petrol. 48, 73-80.

Görz, H., 1974. Microprobe studies of inclusions in zircons and compilation of minor and trace elements in zircons from the literature. Chemie der Erde 33, 4, 326-357.

Medenbach, O.; Ramdohr, P. \& El Goresy, A., 1976. Yttrium, Seltene Erden und Phosphor in Zirkonen als Beispiel für die Anwendbarkeit der automatisierten Mikrosonde in der Geochemie. Fortsch. Mineral. 54, B1, I-II, 142-143.

Robinson, G. W., 1978. The occurrence of rare earth elements in zircon. Ph.D. Dissertation, Queen's University, Kingston, Canada.

Romans, P. A.; Brown, L. L. \& White, J. C., 1975. An plicable to metamict specimens only after heating (at ca $1000^{\circ} \mathrm{C}$ for $4-5$ hours). Experiments show that the intensity of xenotime is not noticeably affected by heating.

Acknowledgements. The work was carried out while the author was at the University of Helsinki. The author is indebted to the late professor Th. G. Sahama of the same university for the specimens used in this work. Dr. Kari Kinnunen critically read the manuscript and Mrs Gillian Häkli corrected the English.

electron microprobe study of yttrium, rare earth, and phosphorus distribution in zoned and ordinary zircon. Am. Mineral. 60, 475-480.

Speer, J. A., 1980. Zircon. Pp. 67-112 in: Orthosilicates (P.H. Ribbe, editor). Reviews in Mineralogy 5. Mineral. Soc. America.

Tennant, C. B. \& Berger, R. W., 1957. X-ray determination of dolomite - calcite ratio of a carbonate rock. Am. Mineral. 42, 23-29.

Törnroos, R., 1982. Composition of metamict zircon from Mozambique. Bull. Geol. Soc. Finland 54, 77-83.

Vorma, A.; Ojanperä, P.; Hoffrén, V.; Siivola, J. \& Lögren, A., 1966. On the rare earth minerals from the Pyörönmaa pegmatite in Kangasala, SW-Finland. Compt. Rend. Soc. géol. Finlande 38, 241-274.

Manuscript received, January 9, 1984. 